\section{Prunus Rootstock Affect Long-term Orchard Performance of 'Redhaven' Peach on Brookston Clay Loam}

\author{
Richard E.C. Layne \\ Agriculture Canada, Research Station, Harrow, Ont., NOR 1G0, Canada \\ Additional index words. Prunus persica, tree size, root suckers, yield, fruit size, yield \\ efficiency, winter hardiness, tree mortality
}

\begin{abstract}
Performance of 'Redhaven' peach [Prunus persica (L.) Batsch.] propagated on nine experimental Prunus rootstock was evaluated over 8 years beginning in 1984, in a randomized complete-block experiment with 10 replications on a Brookston clay loam soil type near Harrow, Ont. This experiment was part of an interregional NC-140 peach rootstock experiment. Significant rootstock-induced effects were noted for increase in trunk cross-sectional area, cumulative tree height and spread, cumulative number of root suckers, yield, average fruit weight, yield efficiency, winter injury, cold hardiness, and tree survival. None of the clonally propagated rootstock gave satisfactory overall performance. All trees on GF655-2, 80\% on GF677, 60\% Self-rooted, and 50\% on GF1869 were dead by the eighth year. In addition, suckering was a major problem on GF1869 and a moderate problem on GF655-2. 'Citation' induced the most scion dwarfing but had the lowest yields and low yield efficiency. When yield, yield efficiency, fruit size, and tree mortality were considered together, the four peach seedling rootstock performed better than the other Prunus rootstocks and were ranked as follows: Siberian C, Halford, Bailey, and Lovell. Of these, the first three could be recommended with the most confidence to commercial growers who grow peaches on fine-textured soils in northern regions.
\end{abstract}

Prunus rootstock can dramatically influence the orchard performance of peach cultivars, affecting such factors as scion growth and development, scion physiology, and orchard design and management (Layne, 1987). The most commonly used rootstock for peach are peach seedlings, interspecific peach hybrids, plums, and plum hybrids (Layne, 1987; Rem, 1983). Other Prunus spp. have also been used, but to a lesser degree, and have not attained worldwide acceptance (Layne, 1987).

Peaches are grown over a wide range of climates and soil types in North America from the Atlantic to the Pacific and from the Great Lakes to the Gulf of Mexico (Hesse, 1975). Broadly adapted rootstocks that tolerate a wide range of climatic edaphic, and biotic stresses could greatly benefit the peach industry and simplify commercial nursery operations. Knowledge of the important attributes and Imitations of specific rootstock is necessary to prevent economic loss from improper peach rootstock recommendations for diverse production regions. For example, while some rootstock, such as Siberian C, perform well in northern regions (Layne et al., 1976, 1977), they are not adapted to more southerly conditions (Dozier et al., 1984; Yadava and Doud,

Received for publication 9 Feb. 1993. Accepted for publication 21 Sept. 1993. The technical assistance of H.O. Jackson, E.W. Lamoure, M.D. St. Pierre, and the statistical advice of N. Zariffa are gratefully acknowledged. The cost of publishing this paper was defrayed in part by the payment of page charges. Under postal regulations, this paper therefore must be hereby marked advertisement solely to indicate this fact.
1980); others, such as Nemaguard, perform well in the south and are poorly adapted in the north (Layne, 1987).

The NC- 140 Technical Committee in 1984 initiated an interregional experiment to evaluate nine Prunus rootstock using 'Redhaven' as the scion. A wide range of climatic zones and soil types were represented by the 16 experimental sites, 15 in the United States and one in Canada. The purpose of this experiment was to determine the range of adaptation of these rootstock over a wide geographic area while identifying individual rootstock that performed best at each site. The test site at Harrow was selected to represent a northerly location, subject to injury from low air and soil temperatures. The Brookston clay loam soil type was selected because it had not been previously tested with all of the rootstock treatments included in the NC-140 trial. This report summarizes 8 years of performance data at the Harrow test site in southwestern Ontario.

\section{Materials and Methods} was a tile-drained Brookston clay loam that also had good surface water drainage. Peaches had never been previously grown on this site. The experimental site was fumigated on 12 Oct. 1983 using 1,3 dichloro propene (Telone II). The fumigant was injected to a depth of 23 $\mathrm{cm}$ at 200 liters $\cdot \mathrm{ha}^{-1}$ and the soil was cultipacked immediately afterwards. Experimental trees were planted in rows oriented north to south to optimize light interception and spaced $4.5 \mathrm{~m}$ in the row with $6.0 \mathrm{~m}$ between rows. Trees were
The Harrow test site $\left(\approx 42^{\circ} \mathrm{N}, \approx 82^{\circ} 54^{\prime} \mathrm{W}\right)$ planted in Spring 1984 in a randomized complete-block design with 10 replications. Each replication was a tree row comprising one tree of each of the nine rootstock treatments. A guard row of an experimental Harrow peach selection (HW242/'Harrow Blood') surrounded the experiment on all four sides. All trees were pruned to an $\mathrm{x}$-form, four-scaffold, open-center system.

Of the nine rootstock treatments, only one (Self-rooted) did not have a graft union and served as a control treatment of the common scion tester 'Redhaven'. Four treatments were peach seedling rootstock (Bailey, Halford, Lovell, Siberian C) and the remaining four were clonally propagated rootstock. They included a natural peach $\times$ almond hybrid (GF677), a presumed plum $\times$ peach hybrid ('Citation'), a St. Julien-typeplum (GF655-2), and a Damas-type plum (GF1 869). The main features of these rootstock have been recently reviewed (Beckman and Cummins, 1991; Layne, 1987; Lichou and Audubert, 1989).

The orchard was managed according to local recommendations for Ontario peach growers (Ontario Ministry of Agriculture and Food, 1991). Row middles were cultivated from April to the end of June, then a cover crop of Italian ryegrass (Lolium multiflorium Lam.) was seeded annually in the first week of July. Weeds in the tree row were controlled using two or more seasonal applications of 1, 1'-dimethyl-4,4'-bipyridinium ion (paraquat). Each year $190 \mathrm{~kg}$ of $0 \mathrm{~N}-10 \mathrm{P}-30 \mathrm{~K}$ fertilizer per hectare was broadcast in the spring. Beginning in 1985, banded application of $\mathrm{NH}_{4} \mathrm{NO}_{3}(34 \mathrm{~N}-$ OP-OK) at the drip line of each tree was made annually in April. In 1985, the rate of $\mathrm{N}$ was $0.02 \mathrm{~kg} /$ tree and was increased by $0.02 \mathrm{~kg} /$ tree per year from 1986 to 1991 .

In the fall of each year, growth measurements were recorded as trunk circumference $30 \mathrm{~cm}$ above the soil surface and converted to trunk cross-sectional area (TCA). In the seventh year (1990), the maximum height and spread of each surviving tree were recorded. Tree spread was measured in the north-south and east-west directions and averaged to give the final value used. Each July from 1986 to 1990 , root suckers were counted and then removed. Yields were recorded from 1986 to 1991 on trees where the crop load was adjusted after the normal June drop by hand-thinning to space fruit $15 \mathrm{~cm}$ apart. Each year the crop was harvested in three to four pickings at normal harvest maturity. Average fruit weight was obtained annually from 1986 to 1991 by recording the weight of a random sample of 50 fruit per treatment per replication from the second pick. Each fall, before leaf drop, trees were counted as dead or alive. Trees that had died in previous years were included in the count of dead trees for any given year. Dead trees were removed and replaced the following year to retain the same tree density, but no data were recorded on replacement trees.

A natural freezing stress of $-26 \mathrm{C}$ occurred on 21 Jan. 1985. Dormant shoots were collected from each tree of each scion-rootstock combination on 23 Jan. 1985, held in plastic bags at high humidity for 5 days at $3 \mathrm{C}$ then 1 
day at $23 \mathrm{C}$ before being assessed for flower bud mortality and shoot xylem injury (Layne, 1982).

On 20 Dec. 1988 and 20 Dec. 1989, dormant shoots were collected from each treatment in each replication and subjected to a standard acclimation, controlled freezing and injury assessment protocol in Jan. 1989 and Jan. 1990, respectively, to determine the $T_{50}$ of flower buds and shoot xylem of maximally acclimated shoots (Layne, 1992). The shoots collected for freezing trials each year included the annual increment of shoot growth made during the 1988 and 1989 growing seasons, respectively.

All data were tested annually by analysis of variance using the SAS general linear models procedure (SAS Institute, Cary, N.C.). Rootstock treatment means were tested using Duncan's multiple range test $(P \leq 0.05)$.

\section{Results}

Tree height and spread in the seventh year (1990). Tree height was similar for all rootstock except those on 'Citation', which were substantially shorter (Table 1). No data were available for trees on GF655-2 because all trees on this rootstock had died by 1990 . Trees with the widest spread were on GF677 and Halford. Those on Siberian C, Bailey, Lovell, Self-rooted, and GF1869 were the next widest but of similar spread. Trees with substantially reduced spread were on 'Citation'.

Increase in TCA. The increase in TCA from 1984 to 1990 (Table 1) was greatest on GF677, then Halford. The next largest trees were on Lovell and Siberian C, which were of similar size. Trees on Self-rooted, Bailey, and GF1869 were next largest but of similar size. Trees on 'Citation' and GF655-2 were substantially dwarfed compared with the others.

Number of root suckers. From the third to the seventh year, the cumulative number of root suckers was highest on GF 1869, intermediate on GF655-2, and very low or absent on the remaining seven rootstock (Table 1).

Annual and cumulative yield (1986-91). Rootstock significantly influenced annual and cumulative yields in the first 6 years of fruit production (Table 2). In the first year of cropping (1986), Siberian C and Lovell had a

Table 1.Tree height and spread in the seventh year (1990), increase in trunk cross-sectional area (TCA) from the first (1984) to the seventh year, and cumulative number of root suckers from the third to the seventh year.

\begin{tabular}{|c|c|c|c|c|}
\hline Rootstock & $\begin{array}{c}\text { Tree ht } \\
1990 \\
(\mathrm{~m}) \\
\end{array}$ & $\begin{array}{c}\text { Tree spread } \\
1990 \\
\text { (m) } \\
\end{array}$ & $\begin{array}{c}\text { Increase in TCA } \\
1984-90 \\
\left(\mathrm{~cm}^{2}\right) \\
\end{array}$ & $\begin{array}{c}\text { No. root } \\
\text { suckers } \\
1986-90 \\
\end{array}$ \\
\hline$\overline{\text { Self-rooted }}$ & $2.98 \mathrm{a}^{2}$ & $5.39 \mathrm{c}$ & $120 \mathrm{c}$ & $0 \mathrm{c}$ \\
\hline Bailey & $3.05 \mathrm{a}$ & $5.45 \mathrm{c}$ & $119 \mathrm{c}$ & $7 \mathrm{c}$ \\
\hline Halford & $3.21 \mathrm{a}$ & $6.33 \mathrm{ab}$ & $160 \mathrm{ab}$ & $0 \mathrm{c}$ \\
\hline Lovell & $3.00 \mathrm{a}$ & $5.41 \mathrm{c}$ & $135 b c$ & $0 \mathrm{c}$ \\
\hline Siberian C & $3.11 \mathrm{a}$ & $5.68 \mathrm{bc}$ & $134 b c$ & $0 \mathrm{c}$ \\
\hline GF677 & $2.95 \mathrm{a}$ & $6.55 \mathrm{a}$ & $177 \mathrm{a}$ & $4 \mathrm{c}$ \\
\hline Citation & $2.09 \mathrm{~b}$ & $3.51 \mathrm{~d}$ & $39 \mathrm{~d}$ & $0 \mathrm{c}$ \\
\hline GF655-2 & --- & --- & $56 \mathrm{~d}$ & $88 \mathrm{~b}$ \\
\hline GF1869 & $2.95 \mathrm{a}$ & $5.20 \mathrm{c}$ & $117 \mathrm{c}$ & $735 \mathrm{a}$ \\
\hline F test & $* *$ & $* *$ & $* *$ & $* *$ \\
\hline
\end{tabular}

${ }^{2}$ Mean separation of rootstock within columns according to Duncan's multiple range test $(P \leq 0.05)$.

** Significant at $P \leq 0.01$. **Significant at $P \leq 0.01$. production.

${ }^{2}$ Based on a random sample of 50 fruit/tree from 10 replications.

ss $* *$ Nonsignificant or significant at $P \leq 0.01$, respectively.

greater effect on precocity than any of the other rootstock and thus the highest yields. The precocity effect was also apparent in the second year (1987), but to a lesser degree. Yields were highest in the third year (1988) on GF677 followed by Halford and Lovell, and were lowest on GF655-2 and 'Citation'. Unfavorable wet weather in the fourth year (1989) resulted in lower yields overall than in 1988, but the rootstock-induced effects on yield were similar to those observed in 1988. Yields in the fifth year (1990) were generally higher overall than in 1989 and were highest on Halford and GF677, and lowest on 'Citation' and GF655-2. In 1991, the sixth and final year in which yields were recorded, the highest yields were on Halford, GF677, and Lovell, while the lowest were on 'Citation' and GF655-2. Cumulative yields for the six years of cropping

Table 2. Yield of 'Redhaven' peach on nine Prunus rootstock in the first 6 years of production.

\begin{tabular}{llcccccc}
\hline & \multicolumn{9}{c}{$\begin{array}{c}\text { Annual yield } \\
(\mathrm{kg} / \mathrm{tree})\end{array}$} & & $\begin{array}{c}\text { Cumulative yield } \\
(\mathrm{kg} / \mathrm{tree})\end{array}$ \\
Rootstock & 1986 & 1987 & 1988 & 1989 & 1990 & 1991 & $1986-91$ \\
\hline Self-rooted & $2.8 \mathrm{~b}^{\mathrm{z}}$ & $28.3 \mathrm{a}-\mathrm{c}$ & $33.7 \mathrm{~cd}$ & $28.1 \mathrm{ab}$ & $48.7 \mathrm{~b}$ & $27.5 \mathrm{bc}$ & 169 \\
Bailey & $2.0 \mathrm{bc}$ & $24.9 \mathrm{bc}$ & $44.1 \mathrm{bc}$ & $32.7 \mathrm{ab}$ & $62.0 \mathrm{~b}$ & $33.4 \mathrm{bc}$ & 199 \\
Halford & $3.1 \mathrm{~b}$ & $30.6 \mathrm{a}-\mathrm{c}$ & $56.3 \mathrm{~b}$ & $41.1 \mathrm{a}$ & $89.5 \mathrm{a}$ & $58.0 \mathrm{a}$ & 279 \\
Lovell & $6.4 \mathrm{a}$ & $38.0 \mathrm{a}$ & $54.5 \mathrm{~b}$ & $24.8 \mathrm{bc}$ & $60.0 \mathrm{~b}$ & $40.4 \mathrm{ab}$ & 224 \\
Siberian C & $7.1 \mathrm{a}$ & $38.5 \mathrm{a}$ & $48.0 \mathrm{bc}$ & $31.0 \mathrm{ab}$ & $66.8 \mathrm{ab}$ & $37.3 \mathrm{a}-\mathrm{c}$ & 229 \\
GF677 & $3.5 \mathrm{~b}$ & $32.9 \mathrm{ab}$ & $75.8 \mathrm{a}$ & $39.6 \mathrm{a}$ & $87.1 \mathrm{a}$ & $40.6 \mathrm{ab}$ & 279 \\
Citation & $0.8 \mathrm{c}$ & $8.4 \mathrm{~d}$ & $11.0 \mathrm{c}$ & $10.1 \mathrm{~d}$ & $15.4 \mathrm{c}$ & $14.8 \mathrm{c}$ & 60 \\
GF655-2 & $2.3 \mathrm{bc}$ & $21.7 \mathrm{bc}$ & $24.5 \mathrm{de}$ & $13.5 \mathrm{~cd}$ & $4.2 \mathrm{c}$ & $14.2 \mathrm{c}$ & 80 \\
GF1869 & $2.6 \mathrm{bc}$ & $21.0 \mathrm{c}$ & $32.7 \mathrm{~cd}$ & $29.9 \mathrm{ab}$ & $45.1 \mathrm{~b}$ & $32.6 \mathrm{bc}$ & 164 \\
F test & $* *$ & $* *$ & $* *$ & $* *$ & $* *$ & $* *$ &
\end{tabular}

${ }^{2}$ Mean separation of rootstock within columns according to Duncan's multiple range test $(P \leq 0.05)$,

Table 3. Average fruit weight of 'Redhaven' peach on nine Prunus rootstock in the first 6 years of fruit

\begin{tabular}{lcccccc}
\cline { 2 - 7 } Rootstock & 1986 & 1987 & 1988 & 1989 & 1990 & 1991 \\
\hline Self-rooted & $110 \mathrm{~cd}$ & $122 \mathrm{~b}$ & $92 \mathrm{ab}$ & $148 \mathrm{a}$ & $135 \mathrm{a}$ & $127 \mathrm{ab}$ \\
Bailey & $109 \mathrm{~cd}$ & $119 \mathrm{~b}$ & $91 \mathrm{a}-\mathrm{c}$ & $137 \mathrm{a}$ & $130 \mathrm{a}$ & $127 \mathrm{ab}$ \\
Halford & $119 \mathrm{bc}$ & $123 \mathrm{~b}$ & $81 \mathrm{bc}$ & $137 \mathrm{a}$ & $126 \mathrm{a}$ & $120 \mathrm{~b}$ \\
Lovell & $135 \mathrm{ab}$ & $113 \mathrm{~b}$ & $88 \mathrm{a}-\mathrm{c}$ & $-154 \mathrm{a}$ & $126 \mathrm{a}$ & $141 \mathrm{a}$ \\
Siberian C & $135 \mathrm{ab}$ & $115 \mathrm{~b}$ & $91 \mathrm{a}-\mathrm{c}$ & $156 \mathrm{a}$ & $133 \mathrm{a}$ & $129 \mathrm{ab}$ \\
GF677 & $127 \mathrm{a}-\mathrm{c}$ & $121 \mathrm{~b}$ & $85 \mathrm{bc}$ & $136 \mathrm{a}$ & $123 \mathrm{a}$ & $123 \mathrm{~b}$ \\
Citation & $95 \mathrm{~d}$ & $120 \mathrm{~b}$ & $103 \mathrm{a}$ & $129 \mathrm{a}$ & $124 \mathrm{a}$ & $121 \mathrm{~b}$ \\
GF655-2 & $132 \mathrm{ab}$ & $130 \mathrm{ab}$ & $79 \mathrm{bc}$ & $96 \mathrm{~b}$ & $86 \mathrm{~b}$ & $-\cdots$ \\
GF1869 & $150 \mathrm{a}$ & $147 \mathrm{a}$ & $75 \mathrm{c}$ & $93 \mathrm{~b}$ & $151 \mathrm{a}$ & $101 \mathrm{c}$ \\
F test & $* *$ & $* *$ & $* *$ & $* *$ & Ns & $* *$ \\
\hline
\end{tabular}

${ }^{y}$ Mean separation of rootstock in columns according to Duncan's multiple range test $(P \leq 0.05)$,

$$
\text { 然 }
$$


Table 4. Yield efficiency of 'Redhaven' peach on nine Prunus rootstock.

\begin{tabular}{|c|c|c|c|c|c|c|c|}
\hline \multirow[b]{2}{*}{ Rootstock } & \multicolumn{6}{|c|}{$\begin{array}{l}\text { Yield efficiency } \\
\quad\left(\mathrm{kg} \cdot \mathrm{cm}^{-2}\right)\end{array}$} & \multirow{2}{*}{$\begin{array}{c}\text { Cumulative yield } \\
\text { efficiency } \\
\left(\mathrm{kg}^{\mathrm{y}} \mathrm{cm}^{-2}\right) \\
1986-91\end{array}$} \\
\hline & 1986 & 1987 & 1988 & 1989 & 1990 & 1991 & \\
\hline Self-rooted & $0.07 b^{x}$ & $0.43 \mathrm{ab}$ & $0.47 \mathrm{bc}$ & $\overline{0.30 \mathrm{a}}$ & $0.43 \mathrm{ab}$ & $0.19 \mathrm{ab}$ & 1.15 \\
\hline Bailey & $0.05 \mathrm{~b}$ & $0.40 \mathrm{ab}$ & $0.57 \mathrm{ab}$ & $0.31 \mathrm{a}$ & $0.51 \mathrm{ab}$ & $0.21 \mathrm{ab}$ & 1.26 \\
\hline Halford & $0.07 \mathrm{~b}$ & $0.37 \mathrm{ab}$ & $0.58 \mathrm{ab}$ & $0.30 \mathrm{a}$ & $0.55 \mathrm{a}^{\circ}$ & $0.28 \mathrm{a}$ & 1.33 \\
\hline Lovell & $0.14 \mathrm{a}$ & $0.51 \mathrm{a}$ & $0.66 \mathrm{a}$ & $0.21 \mathrm{a}$ & $0.44 \mathrm{ab}$ & $0.23 \mathrm{ab}$ & 1.24 \\
\hline Siberian C & $0.15 \mathrm{a}$ & $0.52 \mathrm{a}$ & $0.58 \mathrm{ab}$ & $0.27 \mathrm{a}$ & $0.50 \mathrm{ab}$ & $0.21 \mathrm{ab}$ & 1.29 \\
\hline GF677 & $0.07 \mathrm{~b}$ & $0.32 \mathrm{~b}$ & $0.66 \mathrm{a}$ & $0.25 \mathrm{a}$ & $0.48 a b$ & $0.18 b$ & 1.25 \\
\hline Citation & $0.05 \mathrm{~b}$ & $0.31 \mathrm{~b}$ & $0.38 \mathrm{c}$ & $0.27 \mathrm{a}$ & $0.35 \mathrm{~b}$ & $0.15 \mathrm{~b}$ & 1.05 \\
\hline GF655-2 & $0.07 \mathrm{~b}$ & $0.44 \mathrm{ab}$ & $0.40 \mathrm{c}$ & $0.20 \mathrm{a}$ & $0.05 \mathrm{c}$ & --- & --- \\
\hline GF1869 & $0.07 \mathrm{~b}$ & $0.31 \mathrm{~b}$ & $0.39 c$ & $0.29 \mathrm{a}$ & $0.37 \mathrm{ab}$ & $0.19 \mathrm{~b}$ & 0.95 \\
\hline F test & $* *$ & $* *$ & $* *$ & NS & $* *$ & $* *$ & \\
\hline
\end{tabular}

${ }^{2}$ Yield efficiency $=$ yield/tree per TCA.

${ }^{y}$ Cumulative yield efficiency $=\sum$ (yield $\div$ tree $)(1986-91) /$ TCA $(1991)$.

${ }^{x}$ Mean separation of rootstock in columns according to Duncan's multiple range test $(\mathrm{P} \leq 0.05$. $)$.

${ }^{\mathrm{Ns}}$,**Nonsignificant or significant at $P \leq 0.01$, respectively.

ciency, while 'Citation', GF677, and GF1869 promoted the least. In 1988, a hot, dry, growing season, cropping efficiency was highest on Lovell and GF677, and lowest on GF655-2, 'Citation'; and GF1 869. Cropping efficiency in 1990 was highest on Halford and lowest on GF655-2. Cropping efficiency in 1991 was again highest on Halford, but lowest on 'Citation', GF677, and GF1869. Cumulative yield efficiency from 1986 to 1991, expressed in terms of TCA in 1991, ranked as follows: Halford, Siberian C, Bailey, GF677, Lovell, Self-rooted, 'Citation', and GF1869.

Natural flower bud mortality and shoot xylem injury (1985). Flower bud mortality and xylem injury were assessed following a natural stress of $-26 \mathrm{C}$ on 21 Jan. 1985 (Table 5). Bud mortality ranged from $28 \%$ to $88 \%$ depending on the rootstock. 'Citation' induced the hardiest flower buds in 1985 while Siberian C, Bailey, Lovell, and GF 1869 were intermediate, and the least hardy buds were on GF655-2, GF677, and Self-rooted. Shoot xylem injury also varied by rootstock and ranged from 2.4 (indicating patchy areas of browning

Table 5. Natural flower bud mortality and shoot xylem injury of 'Redhaven' peach on nine Prunus rootstock in $1985 .^{2}$

\begin{tabular}{|c|c|c|}
\hline Rootstocks & $\begin{array}{c}\text { Bud mortality } \\
(\%)\end{array}$ & $\begin{array}{c}\text { Xylem } \\
\text { injury ratingy } \\
(1-5)\end{array}$ \\
\hline$\overline{\text { Self-rooted }}$ & $70.2 a^{x}$ & $2.8 \mathrm{~b}-\mathrm{d}$ \\
\hline Bailey & $60.4 b$ & $2.6 \mathrm{~cd}$ \\
\hline Halford & $74.7 \mathrm{ab}$ & $2.6 \mathrm{~d}$ \\
\hline Lovell & $62.4 \mathrm{~b}$ & $2.4 \mathrm{~d}$ \\
\hline Siberian C & $54.9 \mathrm{~b}$ & $2.6 \mathrm{~d}$ \\
\hline GF677 & $76.2 \mathrm{ab}$ & $2.7 \mathrm{~cd}$ \\
\hline Citation & $28.2 \mathrm{c}$ & $3.2 \mathrm{a}$ \\
\hline GF655-2 & $88.4 \mathrm{a}$ & $3.1 \mathrm{ab}$ \\
\hline GF1869 & $60.2 \mathrm{~b}$ & $3.0 \mathrm{ab}$ \\
\hline F test & $* *$ & $* *$ \\
\hline
\end{tabular}

${ }^{{ }^{2}}$ Minimum temperature -26C, 21 Jan. 1985. Dormant shoots collected from outdoors on 23 Jan. 1985 , held at $3 \mathrm{C}$ for 5 days then at $23 \mathrm{C}$ for $24 \mathrm{~h}$, then assessed for injury.

${ }^{y}$ Xylem rated on a scale of $1=$ absence of browning in xylem cylinder at the midpoint of the shoot to $5=$ entire xylem cylinder dark brown and presumed dead (Layne, 1982).

${ }^{x}$ Mean separation of rootstock in columns by Duncan's multiple range test $(P<0.05)$.

**Significant at $P \leq 0.01$. in the xylem) to 3.2 (indicating that slightly $>50 \sim 0$ of the xylem cylinder was brown). Xylem injury was least on Halford, Lovell, and Siberian C and was greatest on 'Citation', GF655-2, and GF1869. The remaining rootstock had an intermediate effect on xylem hardiness.

$T_{\text {so }}$ for shoot xylem. In 1989, rootstock had a significant influence on shoot xylem hardiness (Table 6). The hardiest xylem was on Siberian C, Lovell, and Halford. The least hardy xylem was on 'Citation' and GF1869. The remaining rootstock had intermediate effects on the hardiness of 'Redhaven' shoots. In 1990, shoot xylem hardiness of 'Redhaven' differed by up to $3.5 \mathrm{C}$, depending on the rootstock. Siberian $\mathrm{C}$ and Bailey induced the hardiest xylem, Self-rooted and Halford induced the next hardiest xylem, then GF677. Lovell, 'Citation', and GF1869 were similar to each other but induced less hardy xylem than those already mentioned, and GF655-2 induced the least hardy shoot xylem of all the rootstock tested.

Tree mortality. Tree mortality in the year

Table 6. Cold hardiness of 'Redhaven' shoot xylem of maximally acclimated shoots on nine Prunus rootstock in 1989 and 1990. ${ }^{2}$

\begin{tabular}{lcc}
\hline & 1989 & 1990 \\
& $\mathrm{~T}_{50}^{\mathrm{y}}$ & $\begin{array}{c}\mathrm{T}_{50}{ }^{\mathrm{y}} \\
\left({ }^{\circ} \mathrm{C}\right)\end{array}$ \\
Rootstocks & $\left({ }^{\circ} \mathrm{C}\right)$ & $-32.7 \mathrm{~cd}$ \\
Self-rooted & $-29.1 \mathrm{~cd}^{\mathrm{x}}$ & $-33.0 \mathrm{~d}$ \\
Bailey & $-29.2 \mathrm{bc}$ & $-32.4 \mathrm{~b}-\mathrm{d}$ \\
Halford & $-29.7 \mathrm{ab}$ & $-31.6 \mathrm{~b}$ \\
Lovell & $-30.0 \mathrm{a}$ & $-33.1 \mathrm{~d}$ \\
Siberian C & $-30.3 \mathrm{a}$ & $-31.9 \mathrm{bc}$ \\
GF677 & $-29.0 \mathrm{bc}$ & $-31.6 \mathrm{~b}$ \\
Citation & $-28.4 \mathrm{c}$ & $-29.6 \mathrm{a}$ \\
GF655-2 & $-27.4 \mathrm{~d}$ & $-31.4 \mathrm{~b}$ \\
GF1869 & $-28.6 \mathrm{c}$ & $* *$ \\
F test & $* *$ & \\
\hline
\end{tabular}

${ }^{2}$ Dormant shoots were collected from outdoors on 20 Dec. 1988 for 1989 data and 20 Dec. 1989 for 1990 daa; acclimated for 21 days at $-3 \mathrm{C}, 7$ days at $-5 \mathrm{C}$, and 7 days at $-10 \mathrm{C}$; then cooled at $5 \mathrm{C} / \mathrm{h}$ to -38C (Layne, 1989).

Temperature required to kill $50 \%$ of the shoot xylem.

${ }^{x}$ Mean separation of rootstock in columns according to Duncan's multiple range test $(P \leq 0.05)$.

$* *$ Significant at $P \leq 0.01$. of establishment (1984) was associated only with self-rooted trees (Table 7). These trees had the smallest root systems of any of the nursery trees planted in 1984. More trees died in 1987 than in any other year, tree mortality being directly related to a mild, wet fall in 1986 that was generally unfavorable for cold acclimation. The first killing frost occurred on 10 Nov. 1986 (-4.5 C), and this was soon followed by a hard freeze $(-10 \mathrm{C})$ on 13 Nov. when trees were only partially defoliated. The remainder of the fall, winter, and spring was relatively mild with no temperatures low enough to predict significant winter injury. Tree mortality in 1987 was highest on GF677, followed by GF655-2, Self-rooted, Lovell, and Siberian C. There was no tree mortality on the remaining rootstock. Injuries sustained in 1987 led to further tree mortality in subsequent years. Thus, by 1991 when trees were in their eighth year, cumulative tree mortality was highest on GF655-2, followed in descending order by GF677, Self-rooted, GF1869, Lovell, Siberian C, Halford, 'Citation', and Bailey. In every case of tree mortality, from 1987 through 1991, winter injury to the trunk and/or root crown was the primary cause of tree death. In general, tree survival was better on peach seedlings than on other rootstock and was best of all on Bailey, the standard peach seedling rootstock used in Ontario.

\section{Discussion}

Rootstock-induced differences in the increase of TCA, tree height, and spread of 'Redhaven' were substantial and increased with tree age (Table 1). GF677 induced the most scion vigor while GF655-2 and 'Citation' induced the least. These findings are in general agreement with those of others for these rootstock (Beckman and Cummins, 1991; Layne, 1987; Lichou and Audubert, 1989). Among the four peach seedling rootstock studied, Halford induced the most scion vigor and Bailey the least, while Siberian $\mathrm{C}$ and Lovell were intermediate. These results contrast with an earlier report (Layne et al., 1977) where Halford and Bailey induced more scion vigor than Siberian C. Siberian C is more shallow-rooted than the other peach seedling rootstock (unpublished data). Drought stress may have contributed to reduced scion vigor in the earlier study conducted on Fox sand, characterized as having low water-holding capacity, low organic matter content $(0.2 \%)$, and low clay $(2.7 \%)$ content (Layne et al., 1986). In the present study, the Brookston clay loam had a higher waterholding capacity, higher organic matter(1.5\%), and higher clay $(28.1 \%)$ content than Fox sand (Tan, 1991). Therefore, drought stress was less frequent, and the dwarfing effect of Siberian $\mathrm{C}$ was not apparent.

Root suckers compete for water and nutrients and require additional labor resources for control. Plum rootstock, in general, are more likely to produce root suckers than peach seedling rootstock (Layne, 1987). A well-known problem associated with GF1 869 is its tendency to produce many root suckers (Bernard 
Table 7. Tree mortality of 'Redhaven' peach on nine Prunus rootstock.

\begin{tabular}{lcccccccc}
\hline & \multicolumn{7}{c}{ Tree mortality (\%) } \\
\cline { 2 - 8 } Rootstocks & 1984 & 1985 & 1986 & 1987 & 1988 & 1989 & 1990 & 1991 \\
\hline Self-rooted & $30 \mathrm{a}^{\mathrm{y}}$ & $30 \mathrm{a}$ & $30 \mathrm{a}$ & $50 \mathrm{a}-\mathrm{c}$ & $50 \mathrm{a}-\mathrm{c}$ & $50 \mathrm{ab}$ & $60 \mathrm{bc}$ & $60 \mathrm{bc}$ \\
Bailey & $0 \mathrm{~b}$ & $0 \mathrm{~b}$ & $0 \mathrm{~b}$ & $0 \mathrm{~d}$ & $0 \mathrm{~d}$ & $0 \mathrm{c}$ & $0 \mathrm{f}$ & $0 \mathrm{f}$ \\
Halford & $0 \mathrm{~b}$ & $0 \mathrm{~b}$ & $0 \mathrm{~b}$ & $0 \mathrm{~d}$ & $0 \mathrm{~d}$ & $10 \mathrm{bc}$ & $10 \mathrm{ef}$ & $10 \mathrm{ef}$ \\
Lovell & $0 \mathrm{~b}$ & $0 \mathrm{~b}$ & $0 \mathrm{~b}$ & $40 \mathrm{bc}$ & $40 \mathrm{bc}$ & $40 \mathrm{a}-\mathrm{c}$ & $40 \mathrm{~cd}$ & $40 \mathrm{~cd}$ \\
Siberian C & $0 \mathrm{~b}$ & $0 \mathrm{~b}$ & $0 \mathrm{~b}$ & $20 \mathrm{~cd}$ & $20 \mathrm{~cd}$ & $20 \mathrm{bc}$ & $20 \mathrm{~d}-\mathrm{f}$ & $20 \mathrm{~d}-\mathrm{f}$ \\
GF677 & $0 \mathrm{~b}$ & $0 \mathrm{~b}$ & $0 \mathrm{~b}$ & $80 \mathrm{a}$ & $80 \mathrm{a}$ & $80 \mathrm{a}$ & $80 \mathrm{ab}$ & $80 \mathrm{ab}$ \\
Citation & $0 \mathrm{~b}$ & $0 \mathrm{~b}$ & $0 \mathrm{~b}$ & $0 \mathrm{~d}$ & $0 \mathrm{~d}$ & $0 \mathrm{c}$ & $10 \mathrm{ef}$ & $10 \mathrm{ef}$ \\
GF655-2 & $0 \mathrm{~b}$ & $0 \mathrm{~b}$ & $0 \mathrm{~b}$ & $60 \mathrm{ab}$ & $70 \mathrm{ab}$ & $70 \mathrm{a}$ & $100 \mathrm{a}$ & $100 \mathrm{a}$ \\
GF1869 & $0 \mathrm{~b}$ & $0 \mathrm{~b}$ & $0 \mathrm{~b}$ & $0 \mathrm{~d}$ & $30 \mathrm{~cd}$ & $40 \mathrm{a}-\mathrm{c}$ & $50 \mathrm{~b}-\mathrm{d}$ & $50 \mathrm{~b}-\mathrm{d}$ \\
F test & $* *$ & $* *$ & $* *$ & $* *$ & $* *$ & $* *$ & $* *$ & $* *$
\end{tabular}

Based on number of dead trees at end of each growing season, including trees that died in previous years. 'Mean separation of rootstock within columns according to Duncan's multiple range test $(P \leq 0.05)$.

** Significant at $P \leq 0.01$.

and Grassely, 1959). GF655-2 is associated with fewer root suckers than GF1 869 (Bernard and Grassely, 1959). Peach seedlings do not normally produce root suckers (Layne, 1987), as also reported here (Table 1).

Yield on a per tree basis is a function of fruit set, thinning intensity, fruit size, tree size, and weather conditions (primarily temperature and rainfall) preceding harvest. In this study, rootstock-induced differences in tree size (Table 1) exerted a parallel influence on fruit yield (Table 2). The largest trees, which were on GF677 and Halford, had the highest cumulative yields while the smallest trees, which were on 'Citation' and GF655-2, had the lowest yields (Tables 1 and 2). Durner and Goffreda (1992) reported their lowest mean yields per tree on GF655-2 and their highest on Lovell in 1989 and 1990. 'Citation' was not included among the rootstock reported in their experiment. In their experiment, they also found that tree vigor was highest on GF677 in 1989 and 1990 and lowest on GF655-2 and GF1 869 in 1989, and lowest on Lovell, GF655-2, and GF1 869 in 1990. Frost injury during bloom was a contributing factor in their yield data, but was not a factor in this study.

Fruit weight is a function of crop load, tree vigor, and growing conditions (primarily temperature and soil moisture) before harvest. Because rootstock influenced tree size (Table 1) and yield (Table 2), they also affected fruit weight (Table 3). Average fruit weight was significantly" influenced by rootstock each year (Table 3). Typically, the largest fruit were on Siberian $\mathrm{C}$ and the smallest were on GF655-2.

Cropping efficiency was generally greater on the four peach seedling rootstock (Siberian $\mathrm{C}$, Lovell, Halford, Bailey) than on the clonally propagated peach $\times$ almond (GF677), Self-rooted, plum $\times$ peach ('Citation'), and plum (GF1869, GF655-2) rootstock (Table 4). Durner and Goffreda (1992) found no significant rootstock-induced differences in production efficiency in 1989, but in 1990 , both GF655-2 and GF1 869 had lower cropping efficiencies than the other rootstock, which were not significantly different from each other. However, they only reported on 2 years of data.

We previously showed (Layne et al., 1977; Layne and Ward, 1978) that peach seedling rootstock influence scion hardiness. . Likewise, it was shown for the rootstock involved in this study that in widely different climatic locations, such as New York (Brown and Cummins, 1988), Missouri (Wartmund and Slater, 1988), New Jersey (Durner, 1990; Durner and Rooney, 1988), and Ontario reported here (Tables 5-7), they differed in their effect on 'Redhaven' scion hardiness. Generally, Siberian $\mathrm{C}$ induced the most scion hardiness and GF655-2 the least. In New York, 'Citation' and GF1 869 induced the most flower bud hardiness while GF655-2 and GF677 induced the least (Brown and Cummins, 1988). When detached shoots were preconditioned to attain maximum hardiness, 'Redhaven' shoots on Siberian C and Bailey were up to $3.5 \mathrm{C}$ more hardy than those on GF655-2 (Table 6). Despite the advantages offered by GF655-2 and GF677 for limiting soil factors and adverse replant situations (Layne, 1987), their negative effects on scion cold hardiness at these four test sites suggest they may not be suitable for regions with low winter temperatures.

In this study, winter injury was the primary cause of tree death in each year except 1984. In a few instances, perennial canker (Leucostoma spp.) was a secondary cause of tree death, and only in 1984, the year of establishment, was tree death directly attributable to the quality of the nursery stock. Self-rooted 'Redhaven' had a poorly developed root system and some trees failed to become successfully established in the first year.

In this, as in other studies (Dozier et al., 1984; Layne et al., 1976; Yadava and Doud, 1980), Prunus rootstock exerted a profound influence on scion mortality with important implications for commercial nursery operators and growers. By the eighth year of this study, scion mortality equalled or exceeded $50 \%$ for GF1 869, Self-rooted, GF677, and GF655-2 rootstock (Table 7). Scion mortality was least on Bailey, followed by Halford, 'Citation', Siberian C, and Lovell. These results contrasted with those from the southeastern United States (Dozier et al., 1984; Yadava and Doud, 1980) where Lovell was associated with less tree mortality than Halford or Siberian $\mathrm{c}$.

The results of this experiment indicate that, for southern Ontario, some of the Prunus rootstock were clearly more suited for commercial peach production than others. Tree mortality by the eighth year equalled or exceeded $50 \%$ on the following clonally propagated rootstock: GF655-2, GF677, Selfrooted, and GF1 869, clearly making them unsuitable for southern Ontario despite any other attributes they exhibited. Root suckering was sufficiently important with GF1 869 that, if not eliminated on the grounds of high tree mortality, it would be eliminated because of the suckering problem. 'Citation' would be eliminated on the basis of very low fruit production and cropping efficiency. Lovell seedlings, associated with $40 \%$ tree mortality compared with those of Siberian C (20\%), Halford $(10 \%)$, and Bailey ( $0 \%)$, was the least satisfactory of these four peach rootstock seed sources. Nevertheless, Lovell performed better than the clonally propagated rootstock just mentioned. When yield, fruit size cropping efficiency, and tree mortality were considered together, 'Redhaven' performed best on seedlings of Siberian $\mathrm{C}$, followed by those on Halford and Bailey. However, all three seed sources were considered satisfactory as rootstock for peach in southern Ontario and could be recommended with confidence to commercial growers, at least for the Brookston Clay Loam soil type.

\section{Literature Cited}

Beckman, T. and J.N. Cummins. 1991, Rootstock for peaches, p. 974. In: J.N. Cummins (ed.). Register of new fruit and nut varieties: Brooks and Olmo List 35. HortScience 26:951-986.

Bernard, R. and C. Grassely. 1959. La pruniers porte-greffes du pêcher. J. Fruit. et Maraich. d'Avignon. p. 75-100.

Brown, S.K. and J.N. Cummins. 1988. Rootstock influenced peach flower bud survival after a natural freeze. HortScience 23:846-847.

Dozier, W.A., Jr., J.W. Knowles, C.C. Carlton, R.C. Rom, E.H. Arrington, E.J. Wehunt, U.L. Yadava, S.L. Doud, D.F. Ritchie, C.N. Clayton, E.I. Zehr, C.E. Gambrell, J.A. Britton, and D.W. Lockwood. 1984. Survival, growth, and yield of peach trees affected by rootstock. HortScience 19:26-30.

Durner, E.F. 1990. Rootstock influence on flower bud hardiness and yield of 'Redhaven' peach. HortScience 25: 172-173.

Dumer, E.F. and J.C. Goffreda. 1992. Rootstockinduced differences in flower bud phenology in peach. J. Amer. Soc. Hort. Sci. 117:690-697.

Durner, E.F. and F.X. Rooney. 1988. 'Rio Oso Gem' and 'Loring' peach flower bud and wood hardiness as affected by different rootstock. Fruit Var. J. 42:134138.

Hesse, C.O. 1975. Peaches, p. 285-335. In: J. Janick and J.N. Moore (eds.). Advances in fruit breeding. Purdue Univ. Press, W. Lafayette, Ind.

Layne, R.E.C. 1982. Cold hardiness of peaches and nectarines following a test winter. Fruit Var. J. 36:90-98.

Layne, R.E.C. 1987. Peach rootstock, p. 185-216. In: R.C. Rom and R.F. Carlson (eds.). Rootstocks for fruit crops. Wiley, New York.

Layne, R.E.C. 1989. Breeding cold hardy peaches for Canada. Acta Hort. 254:73-78.

Layne, R.E.C. 1992. Breeding cold hardy peaches and nectarines, p. 271-306. In. J. Janick (ed.). Plant breeding reviews. vol. 10. Wiley, New York.

Layne, R.E.C., H.O. Jackson, and F.D. Stroud. 1977. Influence of peach seedling rootstock on defo- 
liation and cold hardiness of 'Redhaven' peach. J. Amer. Soc. Hort Sci. 102:89-92.

Layne, R.E.C., C.S. Tan, and R.L. Perry. 1986. Characterization of peach rootstock in Fox sand as influenced by sprinkler irrigation and tree density. J. Amer. Soc. Hort. Sci. 111:670-677.

Layne, R.E.C. and G.M. Ward. 1978. Rootstock and seasonal influences on carbohydrate levels and cold hardiness of 'Redhaven' peach. J. Amer. Soc. Hort. Sci. 103:408-413.

Layne, R.E.C., G.M. Weaver, H.O. Jackson, and
F.D. Stroud. 1976. Influence of peach seedling rootstock on growth, yield and survival of peach scion cultivars. J. Amer. Soc. Hort. Sci. 101:568-572.

Lichou, J. and A. Audubert. 1989. L'abricotier. Ctifl, No. 7496, France.

Ontario Ministry of Agriculture and Food. 1991. 1992-1993 Fruit production recommendations. Publ. 360.

Rem, R.C. 1983. The peach rootstock situation: An international perspective. Fruit Var. J. 37:3-14.
Tan, C.S. 1991. Effect of different water content, sample number, and soil type on determination of soil water using a home microwave oven. Soil Sci. Plant Nutr. 38:381-384.

Warmund, M.R. and J.V. Slater. 1988. Hardiness of apple and peach trees in the NC-140 rootstock trials. Fruit Var. J. 42:20-24.

Yadava, V.L. and S.L. Doud. 1980. The short life and replant problem of deciduous fruit trees, $\mathrm{p}$. 1-1 16. In: J. Janick (ed.). Horticultural reviews. vol. 2. AVI, Westport, Corm. 